\title{
Influence of Body Mass Index, Waist Circumference, and Physical Activity on Age of Menarche in Female Adolescent
}

\author{
Ulfa Puspita Rachma'), Annang Giri Moelyo',2), Imasari Aryani²) \\ 1)Department of Child Health, Dr. Moewardi Hospital, Surakarta \\ 2)Faculty of Medicine, Universitas Sebelas Maret
}

\section{ABSTRACT}

Background: The age of menarche which was referred to first time of teenagers had menstruation can be affected by anthropometric index, including body mass index, and waist circumference. Differences in measurement of body mass index, waist circumference, and intensity of physical activity will make some differences in age of menarche. This research aimed to determine the influence of body mass index, waist circumference and physical activity with age of menarche in late adolescent girls in Surakarta.

Subjects and Method: The data collected by observed 359 adolescent girls aged 15 until 18 years old in Surakarta during September to October 2016 using observational analytic with cross sectional methods. The independent variables were body mass index, waist circumference, and physical activity. The dependent variable is age of menarche. Body mass index is measured using BW $(\mathrm{kg}) / \mathrm{BH}^{2}\left(\mathrm{~m}^{2}\right)$ formula, in which: BW is Body Weight (measured using digital standardized scales) and BH is Body Height (measured using standardized microtoise). Students asked to fill in the questionnaire that contain questions regarding reproductive health especially menarche and physical activity questionnaire (IPAQ). The data is processed using SPSS for Windows 23.0 and are analyzed using multiple regression analysis.

Results: From the 359 respondents, the mean of age of menarche is 12.6 years (Mean=12.6; $\mathrm{SD}=$ 1). Mean of body mass index is $21.42 \mathrm{~kg} / \mathrm{m}^{2}$ (Mean= 21.42; $\left.\mathrm{SD}=4.44\right)$. Mean of waist circumference is $70.41 \mathrm{~cm}(\mathrm{Mean}=70.41 ; \mathrm{SD}=7.47)$. There are 87 respondents $(24.2 \%)$ with low physical activity, 100 respondents (29.5\%) with moderate physical activity, and 166 respondents (46.2\%) with high physical activity. Physical activity has significant influence positively $(\mathrm{OR}=1.98 ; 95 \% \mathrm{CI}=$ 0.39 to $4.72 ; p=0.017$ ) on the age of menarche.

Conclusion: Physical activity has significant influence on the age of menarche in adolescent girls in Kota Surakarta, Indonesia.

Keywords: endocrinology, body mass index, waist circumference, physical activity, menarche, female student

\section{Correspondence:}

Ulfa Puspita Rachma. Faculty of Medicine, Universitas Sebelas Maret. Jl. Ir. Sutami 36A Surakarta 57126, Central Java. Email: ulfapr96@gmail.com. Mobile: 082329342140.

\section{Cite this as:}

Rachma UP, Moelyo AG, Aryani I (2021). Influence of Body Mass Index, Waist Circumference, and Physical Activity on Age of Menarche in Female Adolescent. J Matern Child Health. 06(04): 400-408. https://doi.org/10.26911/thejmch.2021.06.04.02.

(c) (i) (-) Journal of Maternal and Child Health is licensed under a Creative Commons Attribution-NonCommercial-ShareAlike 4.0 International License.

\section{BACKGROUND}

Menarche or the first menstruation takes place as the result of complex hormonal system. Human five senses receive stimulation that is forwarded to the central nerve system and processed by hipotalamus, the stimulation is then sent to hipofise through fortal system, and then gonadropic hormone is secreted that will stimulate follicle and luteinizing hormonto stimulate 
ovary. Follicle stimulating hormone(FSH) stimulates the follicle primordialwhich in its process secretes esterogen, resulting in the growth and secondary sexual mark, this is the sign of adolescent who is experiencing puberty. Menarche is general takes place around the age of 10-11 years old (Manuba, 2001). Several factors that affect the age of menarche are the accumulation of body fat, nutritional intake, environmental condition, socio-economic status, genetic factors, and exposure to endoneurocrine disruptors (Santrock, 2007; Karapanou and Apadimitriou; 2010).

The average age of menarche has decreased gradually. This might be caused by the changes in dietary consumption and the increase in physical activities, psychological stress that affect menstrual cycle. The decreased age of menarche or early menarche may increase the risk of breast cancer, obesity, and miscarriage (Silva et al., 2008). A research in US compared the age of menarche among adolesecent of the same age before 1900 and 1988 to 1994 . The research found that the average age of menarche was above 14 years old in adolesecent before 1990 and 12.4 years old in adolesecent during 1988-1994 (Karapanou and Apadimitriou; 2010). The earliest menarche in Indonesia is nine years old, while the latest menarche is 18 years old. Most of teenage girl in Indonesia experience menarche at 12 years old (31.33\%), 13 years old (31.30\%), and 14 years old (18.24\%) (Batubara et al., 2010). Another anthropometric survey in seven areas of Indonesia find that the age of menarche in Indonesia is varies from 12.5 years old to 13.6 years old (Speroff and March, 2010).

The age of menarche has a strong relationship with body mass index (BMI) for years. Early menarche takes place in overweight women more often than on normal or underweight women (Bosch et al., 2008). The involvement of BMI in the age of menarche is showed in no decrease of the age of menarche in underweight adolesecent (Speroff and March, 2010).

Waist circumference is one of obesity indicators that have a link with menarche. A study conducted on 370 adolesecent girls between 10-16 years old find a significant relationship $(\mathrm{p}=0.040)$ between the age of menarche and waist circumference (Farahmand et al., 2012).

Moderate physical activity in early ages decrease the frequency of ovulation in menstrual cycle (Bernstein et al., 1987). Adolesecent girls with inactive physical activity tend to experience overweight and have faster maturation of sexual function. The age of menarche in children with moderate-active physical activity significantly experience delay in menarche compared to their friends (Ajita and Jiwanjot, 2014). This research aimed to find the effect of BMI, waist circumference, and the intensity of physical activity on the age of menarche in adolesecent in Surakarta, Indonesia.

\section{SUBJECTS AND METHOD}

\section{Study Design}

This was an analytical observational study with cross sectional design. The study was conducted Public High School 3 Surakarta, Central Java, from September to October 2016.

\section{Population and Sample}

The subject of study is students in SMA Public High School 3 Surakarta. A sample of 359 female adolesecent aged 15 to 18 years was selected for this study.

\section{Study Variables}

The dependent variable was age of menarche. The independent variables were body mass index, waist circumference and physical activity. 
Rachma et al./ Body Mass Index, Waist Circumference, Physical Activity, and Menarche

\section{Operational Definition of Variables} Body mass index was calculation using the formula for weight in kilograms divided by the square of height in meters. The weight measurement scale used a calibrated digital weighing scale with capacity of 150 $\mathrm{kg}$ and calibrated at $0.1 \mathrm{~kg}$. The weight scale placed in the even surface and set at ' $O$ ' position and subjects are asked to stand on the scales without their shoes on, and wearing as minimum clothes as possible (Pramanik et al., 2014). The height measurement scale used a calibrated microtoise with the capacity of 2 meters and accuracy of up to $0.1 \mathrm{~cm}$. The measurement is conducted by asking subjects to stand in front of microtoise, face to the scales and without shoes on (Pramanik et al., 2014). The measurement scale is ratio in $\mathrm{kg} / \mathrm{m}^{2}$.

Waist circumference measurement conducted on the midpoint between lower point of rib and the highest point of illiaca with flexible band that is not easily stretched in horizontal position during the end of normal expiration, subject stand straight and facing forward (Pramanik et al., 2015). The measurement used metline with 1 metre capacity and accuracy of up to $0.1 \mathrm{~cm}$. The measurement scale is ratio in centimeter $(\mathrm{cm})$.

Physical activity measured through questionnaire for physical activity or International Physical Activity Questionnaire (IPAQ) includes several columns that consists of: 1). various types of physical activity; 2). The frequency of activity: (never, daily, weekly, monthly, 3 months); and 3). The duration of activity measured in minutes. Respondents are guided to write their answer on the available blank column about the frequency of the activity of each physical acitivity they have daily, weekly, or monthly during the past three months. Then respondents are asked to write the duration of their activity (in minutes) for each activity at a time (Fan et al., 2014). The measurement scale is ratio.

Age of menarche was the age at which women first menstruate, expressed in years. Data gathered using reproduction health questionnaire that is focused on respondent's age of menarche and interviews. The measurement scale is ratio.

\section{Study Instruments}

The instrument used is questionnaire that contains questions regarding reproductive health especially menarche and physical activity questionnaire (IPAQ)

\section{Data Analysis}

The data collected is then analyzed using multiple linear regression analysis to find the effect of BMI, waist circumference, and physical activity on adolesecent age of menarche in Surakarta.

\section{Research Ethics}

Research ethical issues including informed consent, anonymity, and confidentiality, were addressed carefully during the study process. The research ethical clearance approval letter was obtained from the Research Ethics Committee at Dr. Moewardi Hospital, Surakarta, Indonesia, No. 576/VI/HREC/2016 on July 11, 2016 and SMA Negeri 3 Surakarta, Indonesia, No. 070/o802a/2016 on August 31, 2016.

\section{RESULTS}

\section{Sample Characteristics}

Respondent's characteristics based on the descriptive statistic consist of age, age of menarche, BMI, and waist circumference, are presented in Table 1 . In Table 1 showed mean of the age of menarche is 12.6 years $(\mathrm{Mean}=12.6 ; \mathrm{SD}=1)$. The mean of $\mathrm{BMI}$ is $21.42 \mathrm{~kg} / \mathrm{m}^{2}(\mathrm{Mean}=21.42 ; \mathrm{SD}=4.44)$. If the BMI is viewed from BMI/A for $15-18$ age group, $21.42 \mathrm{~kg} / \mathrm{m}^{2}$ is still in the normal limit or median for the age group (Kementrian Kesehatan Republik Indonesia, 2011). Further, mean of waist circum- 
Rachma et al./ Body Mass Index, Waist Circumference, Physical Activity, and Menarche

ference is $70.41 \mathrm{~cm}$ (Mean $=70.41 ; \mathrm{SD}=$ 7.47) $\mathrm{cm}$.

Table 1. Characteristics of the study subject

\begin{tabular}{lcccc}
\hline \multicolumn{1}{c}{ Variable } & Mean & SD & Min. & Max. \\
\hline Age (month) & 199.07 & 11.74 & 109 & 219 \\
Age on menarche (month) & 147.71 & 12.89 & 108 & 191 \\
BMI $^{*}\left(\mathrm{~kg} / \mathrm{m}^{2}\right)$ & 21.42 & 4.44 & 14.11 & 59.35 \\
Waist Circumference(cm) & 70.41 & 7.47 & 53 & 101 \\
\hline
\end{tabular}

The distribution of respondent's data according to the intensity of physical activity can be seen in Table 2 . One hundred and sixty-six students (46.2\%) have heavy physical activity, 106 students (29.5\%) have moderate physical activity, and 87 students (24.2\%) have light physical activity. The

Table 2. Subject characteristics based on physical activity

\begin{tabular}{lcc}
\hline Physical Activity & Total (students) & Percentage (\%) \\
\hline Light & 87 & 24.2 \\
Moderate & 106 & 29.5 \\
Heavy & 166 & 46.2 \\
Total & 359 & 100 \\
\hline
\end{tabular}

\section{The result of multilevel analysis}

The result of data analysis is presented in Table 3. Based on the multiple linear regression analysis, only physical activity classification of light, moderate, and heavy physical activity is based on the data filled by respondents in the questionnaire. The results were then interpreted based on the guideline for data processing and IPAQ analysis.

Table 3. The results of multiple linear regression on the influence of body mass index, waist circumference and physical activity on age of menarche

\begin{tabular}{lcccc}
\hline \multirow{2}{*}{ Independent Variables } & \multirow{2}{*}{ OR } & \multicolumn{2}{c}{ (95\%) CI } & \multirow{2}{*}{ p } \\
\cline { 3 - 4 } & & Lower Limit & Upper Limit & \\
\hline Body Mass Index (BMI) & -0.15 & 0.05 & 0.57 & 0.500 \\
Waist Circumference & -0.24 & 0.07 & 0.79 & 0.070 \\
Physical Activity & 1.98 & 0.39 & 4.72 & 0.017 \\
n observation $=359$ & & & \\
Log likelihood $=-912.72$ & & & \\
Adj R-Square $=0.53$ & & & \\
$\mathrm{p}=0.05$ & & & \\
\hline
\end{tabular}

\section{DISCUSSION}

The age in which adolesecent girl gets their menarche is around 10-16 years old with the mean of 12.5 years old (Saifuddin, 2009). Energy intake affect body growth. If people get inadequate energy intake, it may cause decline in growth, among others are metabolism rate, activity rate, physical appearance, and sexual maturation reflected in the age of menarche (Soetjiningsih, that significantly affect positively the age of menarche $(\mathrm{OR}=1.98 ; \mathrm{p}=0.017)$, while $\mathrm{BMI}$ and waist circumference have no significant effect on the age of menarche ( $p=0.05)$.
2007). The speed of sexual function maturation and accumulation of body fat may affect the age of menarche The acceleration maturation of sexual function and accumulation of body fat may affect the age of menarche in body weight, body mass index, and obesity(Van Lenthe et al., 1996). The accumulation of body fat acts as stimulant in endo-neurokrin during menarche(Frisch and Revelle, 1970). 
The result of this study showed that there is no significant effect $(p=0.500)$ of BMI on the age of menarche in $15-18$ years old adolesecent in Surakarta. This finding is supported by the similar finding from a study in Copenhagen, Denmark, in which there is no relation between BMI and the age of menarche (Aksglaede et al., 2009). There is no significant changes in BMI and the age of menarche that is reflected in early pubarche in 6-8 years old children in Europe (Ibáñez et al., 2006). The result also in line with the result conducted in Gorgan, North Iran, there is no significant relationship between BMI, body height, and body weight with the age of menarche in $788,7-$ 16 years old female adolesecent (Bazrafshan et al., 2012). A study on adolescent girls in Jeddah, Arab Saudi find no significant difference between BMI categories (normal/ underweight and obesity/ overweight) with various categories of the age of menarche (early and normal/late) (Al-Agha et al., 2016).

Several researchers argue that if female adolescent have reached standard weight in entering sexual maturity process, the increase in weight in the future does not accelerate the onset of puberty, which includes menarche (Heger et al., 2008).

Waist circumference on this study obtained the mean value is $70.41 \mathrm{~cm}$ more or less $7.47 \mathrm{~cm}$. This result is underaverage, according to Center for Disease Control and Prevention (CDC), compared to the result of similar measurement in USA in the same age group that generate the mean value of $81.7-83.7 \mathrm{~cm}$ (Fryar et al., 2012). However, it is still normal among waist circumference of adolesecent girls in Asia in general (Tjokroprawiro, 2006). On the research regarding waist circumference and the age of menarche, we find that waist circumference has no significant effect $(\mathrm{OR}=-0.24 ; 95 \% \mathrm{CI}=0.07$ to $0.79 ; \mathrm{p}=$
0.070) on the age of menarche. This result is in line with a study conducted in Guangzhou, China with 7349 respondents. The study finds that waist circumference does not significantly related with the age of menarche (Heys et al., 2007). On adolescent girls who have menarche, there is varies biological measurements (body weight, body height, BMI, waist circumference) which mainly depend on family social status (Dare et al., 1992). A study conducted to 304 adolesecent in Riyadh, Arab Saudi with cross sectional method shows that there is no relationship between BMI, body weight, waist circumference, and hip circumference, and the age of menarche. The study also reveals that researcher measure BMI, body weight, waist circumference, and hip circumference long after the onset of menarche(Shaik et al., 2016).

The result of another study shows that beside anthropometric index such as BMI and waist circumference, there are another factor that affect the age of menarche (such as heredity, genetic, geographical location, lifestyle, and the diference in the level of sexual hormones) (Towne et al., 2005; Hossain et al., 2010). Genetic factors such as early menarche in the family, especially from maternal side has a contribution on the onset of menarche on the girls in the family is revealed by a study conducted in Florida, USA (Guillette et al., 1994). The improvement in lifestyle and living standard, hygieny or health care, nutritional intake, and modernization in Saudi are considered to affect the onset of menarche (Babay et al., 2004). Another factor is stress from psychological factor (inharmonic family relationship, abuse in the family, and death of family member) also affect the onset of menarche (Dare et al., 1992).

From the study on physical activity and the age of menarche, we find a significant relationship $(\mathrm{OR}=1.98 ; 95 \% \mathrm{CI}=0.39$ 
to $4.72 ; \mathrm{p}=0.017)$. Adolesecent with heavy physical activity usually has later onset of menarche compared to their in-age-group friends who have light physical activity. A study on 13-18 years old adolesecent in the South Korea finds that the onset of menarche is affected by physical activity (Lee et al., 2016). Similar result also pointed by a study in Sawla city, South Ethiopia, which find that the age of menarche has a relationship with current age, level of physical activity, vegetable consumption, and education level of parent, but has negative relationship with socio-economic status, increase in weight, increase in calory intake, protein, and the increase in the hours of sleep (Ayele and Berhan, 2013). By comparing the physical acitivy, the researcher find that girls with moderate physical acitivy have later onset of menarche than girls that physically in-active(Khalid et al., 2015).

Physical activity will also add muscle mass rather than body fat. Eventhough the girls with heavy physical acitivity gain weight, they do not have the increase in body fat. Physical activity may decrease the fat tissue which produce leptin and initiate the onset of menarche (Speroff and March, 2010). Active girls burn more calories and generate higher energy than less active girls, thus affecting the secretion of pulsatil Gonadotropin Releasing Hormone (GnRH) which may lead to hiperandrogenisme. Hypothalamus disfunction is related with heavy exercise may disturb the secretion of GnRH which will delay the onset of menarche (Ayele and Berhan, 2013).

Comprehensive effort is needed to sustain growth and sexual development in young children, especially regarding the sign of primary sexual development in girls, menstruation. The need of knowledge on menstruation, including the factors that affect it should be informed earlier to girls and their parents. Further research on the age of menarche by adding various other factors that affect it such as the accumulation of body fat, environmental condition, genetic condition, and socio-economic status is needed.

\section{AUTHOR CONTRIBUTION}

Ulfa Puspita Rachma and Annang Giri Moelyo formulated the conceptual framework and wrote research methodology. Ulfa Puspita Rachma and Imasari Aryani collected and analyzed data.

\section{CONFLICT OF INTEREST}

There is no conflict of interest in this study.

\section{FUNDING AND SPONSORSHIP}

There is no external funding and sponsorship

\section{ACKNOWLEDGEMENT}

We thank Dr. Moewardi Hospital and SMA Negeri 3 Surakarta for their permission and cooperation to conduct the research.

\section{REFERENCES}

Ajita, Jiwanjot (2014). Overweight and physical activity as a measure of age at menarche in females. Am J Sport Sci Med. 2(1): 32-4. https://doi.org/10.12691/ajssm-2-1-6.

Aksglaede L, Sørensen K, Petersen JH, Skakkebaek NE, Juul A (2009). Recent decline in age at breast development: the Copenhagen Puberty Study. Pediatr. 123(5): e932-9. http://doi.org/10.1542/peds.2008-2491.

Al-Agha AE, Ajlan B, Tatwany BO (2016). Trend in age at menarche in relation to body mass index among children and adolescent girls in Saudi Arabia. Res Rev: J Med Health Sci. 5(5): 1-7. https://www.rroij.com/open-access/trend-in-age-at-menarche-in-relation-to-body-mass-index-amongchild- 
Rachma et al./ Body Mass Index, Waist Circumference, Physical Activity, and Menarche

ren-and-adolescent-girls-in-saudiarabia-.php?aid $=77599$.

Ayele E, Berhan Y (2013). Age at menarche among in-school adolescents in Sawla Town, South Ethiopia. Ethiop J Health Sci. 23(3): 189-200. http://doi.org/10.4314/ejhs.v23i3.1.

Babay ZA, Addar MH, Shahid K, Meriki N (2004). Age at menarche and the reproductive performance of Saudi women. Ann Saudi Med. 24(5): 354-6. http://doi.org/10.5144/0256-4947.2004/354.

Batubara JR, Soesanti F, van de Waal HD (2010). Age at menarche in Indonesian girls: A national survey. Acta Med Indones. 42(2): 78-81. https://pubmed.ncbi.nlm.nih.gov/20513931/.

Bazrafshan H, Behnampour N, Sarabandi F, Mirpour S (2012). Association between puberty and weight, height, dan body mass index in a developing community. J Pak Med Assoc. 6(5): 454-7. https://pubmed.ncbi.nlm.nih.gov/22755308/.

Bernstein L, Ross RK, Lobo RA, Hanisch R, Krailo MD, Henderson BE (1987). The effects of moderate physical activity on menstrual cycle patterns in adolescence: implications for breast cancer prevention. Br J Cancer. 55(6): 681685. http://doi.org/10.1038/bjc.1987.139 .

Bosch AM, Willekens FJ, Baqui AH, Van Ginneken JK, Hutter I (2008). Association between age at menarche and early-life nutritional status in rural Bangladesh. J Biosoc Sci Cambridge University Press. 40: 223-37. http://doi.org/10.1017/So021932007002490.

Dare FO, Ogunniyi SO, Makinde OO (1992). Biosocial factors affecting menarche in a mixed Nigerian population. Cent
Afr J Med. 38(2): 77-81. https://pubmed.ncbi.nlm.nih.gov/1505015/.

Farahmand M, Ramezani Tehrani F, Azizi F (2012). Whether age of menarche is influenced by body mass index and lipoproteins profile? a retrospective study. Iran J Reprod Med. 10(4): 337-42. https://pubmed.ncbi.nlm.nih.gov/25246895/.

Frisch RE, Revelle R (1970). Height and weight at menarche and a hypothesis of critical body weights and adolescent events. Sci. 169(3943): 397-9. http://doi.org/10.1126/science.169.3943.397.

Fryar CD, Gu Q, and Ogden CL. Dalam CDC (2012). Vital and health statistics: Anthropometric reference data for children and adults United States, 2007-2010. National Center for Health Statistics, Vital Health Stat: 11 (252). https://www.cdc.gov/nchs/data/series/sr_03/sro3_039.pdf.

Guillette LJ Jr, Gross TS, Masson GR, Matter JM, Percival HF, Woodward AR (1994). Developmental abnormalities of the gonad and abnormal sex hormone concentrations in juvenile alligators from contaminated and control lakes in Florida. Environ Health Perspect. 102(8): 680-8. http://doi.org/10.1289/ehp.94102680.

Heger S, Körner A, Meigen C, Gausche R, Keller A, Keller E (2008). Impact of weight status on the onset and parameters of puberty: analysis of three representative cohorts from central Europe. J Pediatr Endocrinol Metab. 21: 865-77. http://doi.org/10.1515/JPEM.2008.21.9.865.

Heys M, Schooling CM, Jiang CQ, Cowling BJ, Lao X, Zhang W, Cheng KK, Adab $\mathrm{P}$, Thomas GN, Lam TH, Leung GM (2007). Age of menarche and the 
Rachma et al./ Body Mass Index, Waist Circumference, Physical Activity, and Menarche

metabolic syndrome in China. Epidemiol. 18: 740-6. https://www.jstor.org/stable/2O486464.

Hossain G, Islam S, Aik S, Zaman TK, Lestrel PE (2010). Age at menarche of university students in Bangladesh: secular trends and association with adult anthropometric measures and sociodemographic factors. $\mathrm{J}$ Biosoc Sci. 42(5): 677-87. http://doi.org/$10.1017 /$ so021932010000210.

Ibáñez L, Jiménez R, de Zegher F (2006). Early puberty-menarche after precocious pubarche: relation to prenatal growth. Pediatr. 117(1): 117-21. http://doi.org/10.1542/peds.2005-0664.

Fan M, Lyu J, He P (2014). Guidelines for data processing and analysis of The International Physical Activity Questionnaire (IPAQ) 2005. Zhonghua liuxingbingxue zazhi. 35(8):961-4.

Karapanou O, Apadimitriou A (2010). Determinant of menarche. Reprod Biol Endocrinol J. 8: 115. https://doi.org/10.1186/1477-7827-8-115.

Kementrian Kesehatan Republik Indonesia (2011). Keputusan Menteri Kesehatan Republik Indonesia Nomor: 1995/MENKES/SK/XII/2010tentangStand ardAntropometri Penilaian Status Gizi Anak. Jakarta: Kementrian Kesehatan RI,Direktorat Jenderal Bina Gizi dan Kesehatan Ibu dan Anak, Direktorat Bina Gizi 2011.

Khalid H, Khawar K, Fawad M, Farhat M, Imran M, Shahnawaz M, Shahid M, et al. (2015). Age of menarche in relation to socioeconomic status, BMI, physical activity and stress among high school girls. Proceeding S.Z.P.G.M.I; 29(1): 35-40. https://www.researchgate.net/publication/293158240_Age _of_Menarche_in_Relation_to_Soci oeconomic_Status_BMI_Physical_Ac
tivity_and_Stress_Among_High_Sch ool_Girls.

Lee EY, Pabayo R, Kawachi, I (2016). Timing of spermarche and menarche are associated with physical activity and sedentary behavior among Korean adolescents. Osong Public Health Res Perspect. 7(4): 266-272. http://doi.org/10.1016/j.phrp.2016.04.010.

Manuba IBG (2001). Ilmu kebidanan penyakit kandungan dan keluarga berencana. Jakarta: EGC.

Pramanik P, Banerjee SB, Ghosh A (2014). Lifestyle and nutritional status of school going adolescent girls in a semi urban area of West Bengal, India. IOSR J Dent Med Sci. 13(8): 37-42. http://doi.org/10.9790/o853-13833742.

Pramanik P, Rakshit S, Saha P (2015). Physical determinants of early menarche: Study of age at menarche and anthropometric measures in Bengali Girls. Sch J Appl Med Sci. 3(2C): 723-729. https://www.semanticscholar.org/paper/Physical-Determinants-of-EarlyMenarche\%3A-Study-of-PramanikRakshit/oa5837dfc795a8700605839a $638 \mathrm{f} 47 \mathrm{dcb} 46 \mathrm{f} 3 \mathrm{e} 46$.

Saifuddin (2009). Buku acuan pelayanan kesehatan material dan neonatal. Jakarta: Yayasan Bina Pustaka Sarwono Prawirohardjo.

Santrock J (2007).Remaja. Edisi kesebelas. Jilid Pertama, Jakarta: Erlangga.

Shaik SA, Hashim RT, Alsukait SF, Abdulkader GM, AlSudairy HF, AlShaman LM, Farhoud SS, Fouda Neel MA (2016). Assessment of age at menarche and its relation with body mass index in school girls of Riyadh, Saudi Arabia. Asian J Med Sci. 7(2): 5-12. http://doi.org/10.3126/ajms.v7i2.13439. 
Rachma et al./ Body Mass Index, Waist Circumference, Physical Activity, and Menarche

Silva CML, Gigante DP, Minten (2008). Premenstrual symptoms and syndrom according to age at menarche in a 1982 birth cohor in Southhern. Cad Saude Publica. 24(4):835-44. https://doi.org/19.1590/So102-311X2008000400014 .

Soetjiningsih (2007). Tumbuh kembang remaja dan permasalahannya. Jakarta: Sagung Seto.

Speroff L, Marc AF (2010). Clinical endocrinology and fertility Edisi ke-8. Philadelphia: Lippincott Williams \& Wilkins.

Tjokroprawiro A (2006). Hidup sehat dan bahagia bersama diabetes mellitus. Jakarta: Gramedia Pustaka Utama.
Towne B, Czerwinski SA, Demerath EW, Blangero J, Roche AF, Siervogel RM (2005). Heritability of age at menarche in girls from the fels longitudinal study. Am J Phys Anthropol. 128(1): 210-9. http://doi.org/10.1002/ajpa.20106.

Van Lenthe FJV, Kemper HCG, Van Mechelen W (1996). Rapid maturation in adolescence results in greater obesity in adulthood: the Amsterdam growth and health study. Am J Clin Nutr. 64(1): 18-24. http://doi.org/10.1093/ajcn/64.1.18. 